\title{
EDITORIAL: WHAT IS THE FUTURE OF THE ENDOVASCULAR TREATMENT OF INTRACRANIAL ANEURYSMS?
}

\section{LAURENT PIEROT}

\author{
Reims University Hospital, France
}

\begin{abstract}
*Conflict of Interest Statement (We declare that we have no conflict of interest).
*Заява про конфлікт інтересів (Ми заявляємо, що у нас немає ніякого конфлікту інтересів).

*Заявление о конфликте интересов (Мы заявляем, что у нас нет никакого конфликта интересов).
\end{abstract}

*No human/animal subjects policy requirements or funding disclosures.

*Жодний із об'єктів дослідження (людина/тварина) не підпадає під вимоги політики щодо розкриття інформації фінансування.

*Ни один из объектов исследования не подпадает под политику раскрытия информации финансирования.

*Date of submission - 15.05.20

*Дата подачі рукопису - 15.05.20

*Дата подачи рукописи - 15.05.20
*Date of acceptance - 16.06.20

*Дата ухвалення - 16.06.20

*Дата одобрения к печати - 16.06.20

Intracranial aneurysms rapture is a common cause of mortality or morbidity worldwide. For this reason, in case of rupture, early treatment of the aneurysm is mandatory. The evaluation of unruptured intracranial aneurysms continue to increased due to the improvements in invasive and non-invasive neuroimaging. Securing of this life-threatening condition, considering all demographical and procedural factors is necessary for improving treatment results and patients outcome. The endovascular treatment has become frontline therapy of cerebral aneurysms treatment during the last 20 years, and without a doubt its recent advances shifted this boundary even further. Nowadays endovascular armamentarium continues to grow rapidly. Neuro-interventional procedures have tremendously improved their efficiency and continue to improve device's safety. However some types of aneurysms are not really easy to treat with ordinary endovascular technique as it can result in devastating consequence, Firstly, it is not always applicable to complex aneurysms or very large neck aneurysms. Secondly, durability of the of the aneurysm occlusion is not guaranteed in all cases even after usage of the remodeling technique or regular stenting. New devices are introduced to decrease these limits. Two new innovative techniques that are increasingly used for endovacular occlusion of the complex aneurysms are flow diversion and intrasaccular flow disruption. The objective of this review is to provide a comprehensive overview of novel paradigms and latest research of flow diversion and intrasaccular flow disruption devices, its current application, limitation and future prospective. The obvious advantages of these new technologies proved progressive expansion of their utilization to the extent that they will ultimately replace standard coiling in an increasing number of cases going forward.

The future of the endovascular treatment of intracranial aneurysms is bright. Fast growing improvement in vascular access, treatment modalities and device delivery continue 
to increase number of patients with intracranial aneurysms treated with endovascular approach versus surgical clipping.

Key words: intracranial aneurysms; endovascular treatment; flow diversion; intrasaccular flow disruption.

The prevalence of intracranial aneurysms (IA) in the population is high, close from $3 \%$ [1]. The major risk of an IA is its rupture leading to intracranial bleeding (subarachnoid, parenchymal, and/or intraventricular hemorrhage), which is associated with a high case fatality (between 40 to $50 \%$ ) [2].

After the initial aneurysm rupture, the aneurysm wall is fragile and a re-rupture with a new bleeding can be observed, singularly in the days following the initial event. For this reason, in case of rupture, early treatment of the aneurysm is mandatory. After publication of ISAT (International Subarachnoid Trial) results, treatment of ruptured aneurysms has progressively shifted from surgical approach (clipping) to endovascular treatment (EVT) with intrasaccular coiling [3]. EVT is now the first-line treatment in the management of ruptured aneurysms [4].

With the development of non-invasive vascular imaging (Computed Tomography Angiography (CTA) or Magnetic Resonance Angiography (MRA)), aneurysms are more and more discovered before any rupture. The treatment of such unruptured aneurysms is still a matter of debate as the individual risk of bleeding is very difficult to evaluate. From large studies, the risk of rupture is increasing with aneurysm size and in some aneurysm locations (posterior circulation) $[5,6]$. Subsequently the strategy of treatment of patients with unruptured aneurysms is defined on an individual basis taking into account several factors including patient's age, aneurysm's size and location, patient's risk factors, etc $[7,8]$.

IA coiling: limits and additional techniques (balloon-assisted coiling and stent-assisted coiling)

The first endovascular approach used on a large extent for the treatment of IA was coiling using controlled-detachable coils [9]. However

\footnotetext{
Laurent Pierot

PhD (interventional neuroradiology), professor of Radiology, Faculty of Medicine, Reims. President of the French Society of Neuroradiology (SFNR), Head of the Department of Radiology, University Hospital, Reims, France Adress: France, 51100 Reims, 45 Rei Cognace Phone: +33326788764

E-mail:lpierot@gmail.com ORCID ID: 0000-0002-2523-4909
}

as several types of aneurysm can be encountered according to their shape (sacciform/fusiform), size (small/large/giant), neck size (narrow/wide neck), and location, this treatment was rapidly facing some limitations. Wide-neck and fusiform aneurysms are not really easy to treat with coils that have a tendency to migrate into the parent vessel with a risk of parent vessel occlusion.

The remodeling technique or balloon-assisted coiling (BAC, temporary inflation of a balloon in front of the neck during deposition of the coils) was subsequently developed for such wide neck aneurysms with quite good results [10-12]. An alternative approach for wide-neck aneurysms was subsequently proposed with stenting that was used to support the coils placed in the aneurysm. Initial evaluation showed a good efficacy at the price of a relatively high morbimortality rate [13]. Further developments of intracranial stents and increased skills of the physicians using them, was progressively associated with a decreasing morbidity and mortality [14].

Despite these technical developments, the endovascular treatment of IA still has some limitations. First of all, it is not always applicable to complex aneurysms such as fusiform aneurysms or very large neck aneurysms. Secondly, even if the endovascular treatment of some complex aneurysms is now feasible using the remodeling technique or regular stenting, the long-term stability of aneurysm occlusion is not guaranteed in all aneurysms. Thus large and giant aneurysms, wide neck aneurysms, and also more regular aneurysms are candidates for aneurysm reopening (recanalization) [15].

The difficulties encountered in the treatment of some complex IA with coils has lead to the development of 2 new techniques that are progressively increasingly used in their management: flow diversion and intrasaccular flow disruption.

\section{Flow Diversion}

Flow diverters are stents with a very dense mesh. Their goal is primarily to reconstruct the diseased vascular segment harboring the saccular or fusiform aneurysm pouch. The device used for parent vessel reconstruction produces hemodynamic and biological effects: 
- flow redirection: the flow diverter crosses the aneurysm neck and diverts the blood flow from the aneurysm sac, thus reducing shear stress on the aneurysm wall and promoting intra-aneurysm flow stasis and thrombosis. This phenomenon is affected by the amount of metal surface area coverage provided by the stent;

- tissue overgrowth: the flow diverter provides scaffolding for the development of endothelial and neointimal tissue across the aneurysm neck.

The first prospective, multicenter study evaluating flow diversion was PUFS (Pipeline for Uncoilable or Failed Aneurysms) conducted with a first-generation device (Pipeline Embolization Device, Medtronic, Minneapolis, Minnesota, USA) [17]. This study was showing an acceptable safety and efficacy in the treatment of large and giant unruptured internal carotid artery (ICA) aneurysms (see below). Subsequently initial indications were focused on large and giant unruptured ICA aneurysms as well as recanalized or residual aneurysms. ${ }^{18}$ The great efficacy of this treatment demonstrated in further studies (see below) and the development of new-generation flow diverters including small diameters devices (FRED/FREDJr, Microvention, Aliso Viejo, CA, USA; p64/p46-MW/p64-MW, phenox, Bochum, Germany) was leading to the progressive enlargement of indications to small aneurysms, distal aneurysms, and bifurcation aneurysms [19, 20]. One major limitation in the use of flow diverters is the need of using dual antiplatelet treatment (DAPT) preoperatively and in the months (usually 3 to 6 months) following the procedure (see below). Accordingly ruptured aneurysms are not considered as an appropriate indication, except in some specific situations [21].

Complications encountered when treating an aneurysm with flow diverters are, as for coiling, thromboembolic events and intraoperative rupture [22]. Other complications rarely encountered can be seen after aneurysm flow diversion like delayed aneurysm rupture and delayed remote hematoma [23, 24]. As after aneurysm coiling, delayed thromboembolic complications can occur after aneurysm treatment with flow diversion, but on the contrary to coiling these delayed events can occur very late $[25,26]$.

Initial studies dedicated to aneurysm treatment with flow diversion were showing relatively high morbidity and mortality [17, 27]. Pipeline embolization device was the first to be evaluated in large, multicenter series including PUFS. In the cumulated population of 3 multicenter series (1092 patients with 1221 aneurysms), the major neurological morbidity was $5.7 \%$, whereas neurological mortality was $3.3 \%$ [28]. Surpass flow diverter (Stryker Neurovascular, Fremont, CA, USA) was also evaluated in a multicenter trial $($ SCENT $=$ Surpass Intracranial Aneurysm Embolization System Pivotal Trial to Treat Large or Giant Wide Neck Aneurysms) that included 180 patients with 180 aneurysms. 12-month major ipsilateral stroke or neurological death rate was $8.3 \%$ [29]. These morbidity and mortality rates are clearly higher to what is reported with coiling $(1.7 \%$ and $1.4 \%$, respectively, in Analysis of Treatment by Endovascular Approach of Non ruptured Aneurysms [ARETA] study) [30].

With more recent flow diverter generations, the safety was improving probably due to several factors including improvement of flow diverter design, increased skills of the physician, and change in the use of medications used. In SAFE study evaluating FRED/FREDJr flow diverters, cumulative 1-year morbidity and mortality rates were $1.9 \%$ and $2.9 \%$, respectively [31].

Initial experience with p64 and p48 flow diverters was reported in several single-center and multicenter series showing low morbidity and mortality. Fischer et al. reported a series of 121 patients with 130 aneurysms treated with p64 device with transient and permanent morbidity and mortality in $5.0 \%, 1.7 \%$, and $0.8 \%$, respectively [32]. Briganti et al. reported a multicenter series of 40 patients and 50 aneurysms treated with p64 with low morbidity $(2.5 \%)$ and no mortality [33]. In Morais el al. series, 35 patients with 41 IA were treated with p64 with no permanent morbidity or mortality and $5.7 \%$ transient neurological morbidity [34]. Finally in a large singlecenter series of 108 patients with 109 aneurysms permanent morbidity was $1.9 \%$ and no mortality was reported [35]. Clinical experience with p48 reported in the literature is more limited with one single-center series of 25 patients with 25 aneurysms treated with the device with no mortality or morbidity related to the device [36].

Regarding efficacy, the experience with flow diverters reported in the literature has shown two important things:

1) Flow diversion is associated with a very high rate of complete aneurysm occlusion at 6-month or more follow-up (Table). At 6 months rate of complete aneurysm occlusion is between 
$61.1 \%$ and $82 \%$, whereas at one year it is between $66.1 \%$ and $88.0 \%$.

2) On the contrary to what is observed with coiling, aneurysm occlusion after flow diversion is a slow process. When an aneurysm is treated by selective occlusion using coils, intraaneurysmal thrombosis will rapidly occur affording immediate protection against bleeding or rebleeding. On the contrary, complete occlusion is rarely obtained at the end of the flow diversion procedure and will take few months to occur. As demonstrated for instance in PUFS, the rate of complete aneurysm occlusion after flow diverter treatment is $73.6 \%$ at 6-month, $86.8 \%$ at 1 -year, $93.4 \%$ at 3 -year, and $95.2 \%$ at 5-year [37].

To overcome the limitation represented by the need of DAPT, flow diverters with surface modification associated with less platelet aggregation are available and have been used clinically:

1) Pipeline with Shield technology: the Shield technology is a surface modification where a synthetic phosphorylcholine polymer is covalently bonded to the strands that make up the Pipeline braid [38]. A preliminary evaluation of the device was conducted in a prospective, single arm, multicenter study (PFLEX = Pipeline Flex Embolization Device with Shield Technology study) showing a good safety under DAPT in 50 patients [38]. Another single-arm study conducted under DAPT (SHIELD = Pipeline Flex with Shield Technology Embolization - An International, Multicenter Observational Post-Market Study) showed in a population of 205 patients $2.9 \%$ major stroke leading to $1.0 \%$ neurological death [39]. Complete aneurysm occlusion was obtained in $70.8 \%$ at 6-month and $77.2 \%$ at 12-month. In a non-industry-sponsored study $($ PEDSU $=$ Pipeline Embolization Device with Shield Technology in Unruptured Aneurysms) with DAPT, the cumulative morbidity and mortality at 1-year were slightly higher $(6.8 \%$ and $2.3 \%$, respectively) [40]. Complete aneurysm occlusion was reported in $69.2 \%$ at 6 -month and $82.7 \%$ at 18 -month. A limited evaluation was conducted in a small group of 14 patients with ruptured aneurysms treated in the acute phase of bleeding with SAPT (aspirin) [41]. Permanent treatment-related morbidity and mortality occurred in $7.1 \%$ and $7.1 \%$, respectively, which is quite high in comparison with the worse results of bare Pipeline treatment with DAPT. As of now, no comparative study involving Pipeline Shield has been published.

2) p48-MW and p64-MW with HPC (Hydrophilic Polymer Coating) surface modification: Hydrophilic Polymer Coating is a newly developed glycan-based multilayer hydrophilic polymer coating that has been shown to reduce thrombogenicity when applied to nitinol surface [42]. Limited clinical experience with p48-MWHPC and p64-MW-HPC has been published. In a small series of 8 patients with ruptured aneurysms treated with p48-MW-HPC under SAPT (aspirin or prasugrel), intraprocedural transient thrombus formations was observed in $50 \%$ of patients, whereas intra-stent thrombus formation was observed at day 3 [43].

\section{Intrasaccular flow disruption}

Intrasaccular flow disruption (IS-FD) is an innovative approach that involves the placement of a self-expanding, roughly spherically-shaped, cage-like device within the aneurysm [44-49].

Table. Rate of complete aneurysm occlusion in different flow diverter series, \%

\begin{tabular}{|c|c|c|c|c|c|c|}
\hline Series or Authors & Device & 3-month & 6-month & 1-year & 3-year & 5-year \\
\hline DIVERSION [27] & Multiple & - & - & 68.4 & - & - \\
\hline PUFS [37] & Pipeline & - & 73.6 & 86.8 & 93.4 & 95.2 \\
\hline $\begin{array}{c}\text { PUFS+IntrePED+ } \\
\text { ASPIRe [28] }\end{array}$ & Pipeline & - & 75.0 & 85.5 & - & - \\
\hline SCENT [29] & Surpass & - & - & 66.1 & - & - \\
\hline SAFE [31] & $\begin{array}{c}\text { FRED/ } \\
\text { FREDJr }\end{array}$ & - & 61.1 & 73.3 & - & - \\
\hline Fischer [32] & P64 & - & 79.6 & 85.7 & - & - \\
\hline Briganti [33] & p64 & 60.0 & 82.0 & 88.0 & - & - \\
\hline Bhogal [36] & P48 & - & 75.0 & 70.0 & - & - \\
\hline
\end{tabular}


This construct disrupts blood flow at the level of the aneurysm neck and induces intra-aneurysmal thrombosis. Only one intra-saccular flow diversion device, the Woven EndoBridge (WEB), is currently commercially available worldwide (Sequent Medical, Aliso Viejo, CA). The WEB device has been extensively evaluated in several high quality, prospective trials (WEBCAST, WEBCAST-2, US WEB-IT, the French Observatory and CLARYS) [50-56].

The WEB was initially designed to treat wide-neck bifurcation aneurysms arising at the proximal bifurcations, including the internal carotid artery terminus (ICAt), basilar artery (BA), anterior communicating artery (Acom), and middle cerebral artery (MCA). The progressive improvement of the technology (dual-layer to single-layer devices, enhanced visualization, reduction in size of the microcatheter) has lead to an expansion of the potential clinical indications to more distal aneurysms (i.e. pericallosal) and sidewall aneurysms (i.e. carotid siphon) in the EU $[57,58]$.

WEB treatment is associated with an extremely high level of procedural safety, which has been consistently observed in all of the existing prospective trials. In the cumulative population of the $3 \mathrm{GCP}$ studies conducted in Europe (168 patients/169 aneurysms), the rate of any thromboembolic (TE) event was $14.4 \%$, but TE events with permanent deficit were reported in only $3.0 \%$ of cases [55]. Hemorrhagic complications (intraprocedural rupture or intracranial hemorrhage) were reported in $1.8 \%$ and were all asymptomatic. Finally, the mortality at one month was $0.0 \%$ and the morbidity was $3.0 \%$ [55]. Very similar results were reported in the US WEB-IT trial with one-month mortality at $0.0 \%$ and morbidity at $0.7 \%$ [56].

WEB treatment is also associated with a good efficacy in term of anatomical results. In the cumulative population of the 3 European GCP stu-

\section{References}

1. Vlak MHM, Algra A, Brandenburg R, Rinkel GJE. Prevalence of unruptured intracranial aneurysms with emphasis on sex, age, comorbidity, country, and time period: a systematic review and meta-analysis. Lancet Neurol. 2011;10:626-36. PMID: 21641282 doi: 10.1016/S1474-4422(11)70109-0

2. Niewcamp DJ, Setz LE, Algra A et al. Changes in case fatality of aneurysmal subarachnoid haemorrhage over time, according to age, sex, and region: a meta-analy- dies (which included primarily wide neck bifurcation aneurysms), anatomical results at one year were complete occlusion in $52.9 \%$, neck remnant in $26.1 \%$, and aneurysm remnant in $20.9 \%$ [55]. The rate of adequate occlusion (complete occlusion or neck remnant) was $79.1 \%$. Long-term anatomical results (2 years for the 3 European GCP, 3 years for WEBCAST and WEBCAST-2) were recently published showing the great stability of WEB aneurysm treatment $[59,60]$.

\section{Conclusions}

The tools for the endovascular management of intracranial aneurysms continue to evolve rapidly. Flow diversion and intrasaccular flow disruption are the most recent innovation in the field.

Flow direction is the endovascular technique that is associated with the highest rate of complete aneurysm occlusion in long-term followup with no aneurysm recanalization observed in the long term. If the safety of this technique was at its beginning relatively worse compared to coiling with or without balloon- or stent-assistance, the recent development of new generation flow diverters, the improved skills of the physicians, and the optimization of perioperative medications has conduced to the decrease of complications and improved morbidity and mortality rates. Development of surface-modified flow diverters will potentially enlarged indications for this technique, singularly for ruptured aneurysms.

Intrasaccular flow disruption is associated with a great safety and a good efficacy in comparison to aneurysm coiling for similar aneurysms.

According to the great safety and good efficacy of intrasaccular flow disruption and the great efficacy and good safety of flow diversion, there will very likely be a progressive expansion of the indications for both techniques to the extent that they will ultimately replace standard coiling in an increasing number of cases going forward.

sis. Lancet Neurol. 2009;8:635-42. PMID: 19501022 doi: 10.1016/S1474-4422(09)70126-7

3. Molyneux AJ, Kerr RSC, Stratton I, Sandercock P, Clarke M, Shrimpton J, Holman R; International Subarachnoid Aneurysm Trial (ISAT) Colaborative Group: International Subarachnoid Aneurysm Trial (ISAT) of neurosurgical clipping versus endovascular coiling in 2143 patients with ruptured intracranial aneurysms: a randomised trial. Lancet. 2002;360:1262-3. PMID: 12414200 doi: 10.1016/ s0140-6736(02)11314-6 
4. Conard C, Pierot L, Anxionnat R, Ricolfi F, Clarity Study Group. Results of embolization used as the first treatment choice in a consecutive nonselected population of ruptured aneurysms: Clinical results of the Clarity GDC study. Neurosurgery. 2011;69:837-41. PMID: 21623247 doi: 10.1227/NEU.0b013e3182257b30

5. Unruptured intracranial aneurysms: natural history, clinical outcome, and risks of surgical and endovascular treatment. ISUIA investigators. Lancet. 2003;362:103-10. PMID: 12867109 doi: 10.1016/ s0140-6736(03)13860-3

6. Pierot L, Barbe C, Ferré JC et al. Patient and aneurysm factors associated with aneurysm rupture in the population of the ARETA study. J Neuroradiol. 2020 Jun;47(4):292-300. PMID: 31539582 doi: 10.1016/j. neurad.2019.07.007.

7. Pierot L, Gawlitza M, Soize S. Unruptured intracranial aneurysms: management strategy and current endovascular treatment options. Expert Rev Neurother. 2017;17:977-86. https://doi.org/10.1080/14737175.20 17.1371593

8. Pierot L, Gawlitza M, Soize S. Unruptured intracranial aneurysms: It's not a bomb! Rev Neurol. 2017;173:530-1. PMID: 29031554 doi: 10.1016/j.neurol.2017.05.018.

9. Pierot L, Wakhloo AK. Endovascular treatment of intracranial aneurysms: current status. Stroke. 2013;44:2046-54. PMID: 23798560 doi: 10.1161/ STROKEAHA.113.000733

10. Pierot L, Spelle L, Leclerc C et al. Endovascular treatment of Unruptured Intracranial Aneurysms : Comparison of Safety of remodeling technique and standard treatment with coils. Radiology. 2009;251:846-55. PMID: 19318586 doi: 10.1148/radiol.2513081056

11. Pierot L, Cognard C, Anxionnat R, Ricolfi F, for the CLARITY group. The remodelling technique for endovascular treatment of ruptured intracranial aneurysms had a higher rate of adequate occlusion than did conventional coil embolization with comparable safety. Radiology. 2011;258:546-53. PMID: 21131582 doi: 10.1148/radiol.10100894

12. Pierot L, Cognard C, Spelle L, Moret J. Safety and efficacy of balloon remodeling technique during endovascular treatment of intracranial aneurysms: critical review of the literature. AJNR Am J Neuroradiol. 2012;33:12-5. doi: https://doi.org/10.3174/ajnr.A2403

13. Piotin M, Blanc R, Spelle L et al. Stent-assisted coiling of intracranial aneurysms: clinical and angiographic results in 216 consecutive aneurysms. Stroke. 2010;41:110-5. PMID: 19959540 doi: 10.1161/ STROKEAHA.109.558114

14. Cagnazzo F, Cappucci M, Lefevre PH et al. Treatment of intracranial aneurysms with self-expandable braided stents: a systematic review and metaanalysis. AJNR Am J Neuroradiol. 2018;39:2064-9. doi: https:// doi.org/10.3174/ajnr.A5804

15. Ferns SP, Sprengers MES, von Rooij WJ at al. Coiling of intracranial aneurysms: a systematic review on initial occlusion and reopening and retreatment rates. Stroke. 2009;40:e523-9. PMID: 19520984 doi: 10.1161/STROKEAHA.109.553099
16. Pierot L. Flow diverters stents in the treatment of intracranial aneurysms: Where are we? J Neuroradiol. 2011;38:40-6. PMID: 21257202 doi: 10.1016/j.neurad.2010.12.002

17. Beckse T, Kallmes DF, Saatci I et al. Pipeline for Uncoilable or failed aneurysms: Results from a multicenter, clinical trial. Radiology. 2013;267:858-68. PMID: 23418004 doi: 10.1148/radiol.13120099

18. Benaissa A, Januel AC, Herbreteau D et al. Endovascular treatment with flow diverters of recanalized and multitreated aneurysms initially treated by endovascular approach. J Neurointerv Surg. 2015;7:44-9. PMID: 24449174 doi: 10.1136/neurintsurg-2013-011046

19. Pierot L, Spelle L, Berge J et al. Feasibility, complications, morbidity, and mortality results at 6 months for aneurysm treatment with the Flow-Redirection Endoluminal Device: Report of SAFE study. J Neurointerv Surg. 2018;10:765-70. PMID: 29352057 PMCID: PMC6204937 doi: 10.1136/neurintsurg-2017-013559

20. Limbucci N, Leone G, Renieri L et al. Expanding indications for flow diverters: distal aneurysms, bifurcation aneurysms, small aneurysms, previously coiled aneurysms and clipped aneurysms, and carotid cavernous fistulas. Neurosurgery 2020;86:S85S94. PMCID: PMC6911737 PMID: 31838532 doi: 10.1093/neuros/nyz334

21. Kan P, Sweid A, Srivatsan A, Jabbour P. Expanding indications for flow diverters: ruptured aneurysms, blister aneurysms, and dissecting aneurysms. Neurosurgery. 2020;86:S96-S103. PMID: 31838529 doi: 10.1093/neuros/nyz304

22. Pierot L, Barbe C, Nguyen HA, et al. Intraoperative complications of endovascular treatment of intracranial aneurysms with coiling or balloon-assisted coiling in a prospective multicenter cohort of 1088 patients (Analysis of Recanalization after Endovascular Treatment of intracranial Aneurysm [ARETA] study). Radiology. 2020;295:381-9. https://doi.org/10.1148/ radiol.2020191842

23. Kulcsar Z, Houdart E, Bonafe A et al. Intraaneurysmal thrombosis as a possible cause of delayed aneurysm rupture after flow diversion treatment. AJNR Am J Neuroradiol. 2011;32:20-5. PMID: 21071538 doi: 10.3174/ajnr.A2370

24. Benaissa A, Tomas C, Clarençon F et al. Retrospective analysis of delayed intraparenchymal hemorrhage after flow diverter treatment: presentation of a retrospective multicenter trial. AJNR Am J Neuroradiol. 2016;37:475-80. PMID: 26514605 doi: 10.3174/ajnr.A4561

25. Guédon A, Clarençon F, Di Maria F et al. Very late ischemic complications in flow diverter stents: A retrospective analysis of a single-center series. J Neurosurg. 2016;125:929-35. PMID: 26824382 doi: 10.3171/2015.10.JNS15703

26. Pierot L, Barbe C, Herbreteau D et al. Delayed thromboembolic events after coiling of unruptured intracranial aneurysms in a prospective cohort of 335 Patients. Stroke (in press) 
27. Gory B, Berge J, Bonafé A et al. Flow diverters for intracranial aneurysms: The Diversion national prospective cohort study. Stroke. 2019;50:3471-80. PMID: 31765296 doi: 10.1161/STROKEAHA.119.024722

28. Kallmes DF, Brinjikji W, Cekirge $S$ et al. Safety and efficacy of the Pipeline embolization device for treatment of intracranial aneurysms. J Neurosurg. 2017;127:77580. PMID: 27791519 doi: 10.3171/2016.8.JNS16467

29. Meyers PM, Coon AL, Kan PT, Wakhloo AK, Hanel RA. SCENT Trial. Stroke. 2019;50:1473-9. https://doi. org/10.1161/STROKEAHA.118.024135

30. Pierot L, Spelle L, Vitry F. Immediate clinical outcome of patients harboring unruptured intracranial aneurysms treated by endovascular approach: Results of the ATENA Study. Stroke. 2008;39:2497-504. PMID: 18617659 doi: 10.1161/STROKEAHA.107.512756

31. Pierot L, Spelle L, Berge J et al. SAFE study (Safety and efficacy analysis of FRED embolic device in aneurysm treatment): 1-Year clinical and anatomical results. J Neurointerv Surg. 2019;11:184-9. PMID: 30297539 PMCID: PMC6582717 doi: 10.1136/neurintsurg-2018-014261

32. Fischer S, Aguilar-Pérez M, Henkes E et al. Initial experience with p64: a novel mechanically detachable flow diverter for the treatment of intracranial saccular sidewall aneurysms. AJNR Am J Neuroradiol. 2015;36:2082-9. PMID: 26272970 doi: 10.3174/ ajnr.A4420

33. Briganti F, Leone G, Ugga L et al. Mid-term and long-term follow-up of intracranial aneurysms treated with the p64 flow modulation device: a multicenter experience. J Neurointerv Surg. 2017;9:70-6. PMCID: PMC5264236 PMID: 27439887 doi: 10.1136/ neurintsurg-2016-012502

34. Morais R, Mine B, Bruyère PJ, Naeije G, Lubicz B. Endovascular treatment of intracranial aneurysms with the p64 flow diverter: mid-term results in 35 patients with 41 aneurysms. Neuroradiology. 2017;59:263-69. PMID: 28236050 doi: 10.1007/s00234-017-1786-2

35. De Beule T, Boulanger T, Heye S et al. P64 flow diverter: results in 108 patients from a single center. Interv Neuroradiol. 2020 Jun 6;1591019920932048. PMID: 32506988 doi: 10.1177/1591019920932048

36. Bhogal P, Bleise C, Chudyk J et al. The p48MW flow diverter: initial human experience. Clin Neuroradiol. 2019 PMID: 31435722 doi: 10.1007/s00062-01900827-8

37. Becske T, Brinjikji W, Potts MB et al. Long-term clinical and angiographic outcomes following Pipeline embolization device of complex internal carotid artery aneurysms: Five-year results of the Pipeline for Uncoilable or Failed Aneurysms Trial. Neurosurgery. 2017;80:40-8. PMID: 28362885 doi: 10.1093/neuros/ nyw014

38. Martinez-Galdamez M, Lamin SM, Lagios KG et al. Periprocedural outcomes and early safety with the use of Pipeline Flex embolization device with Shield technology for unruptured intracranial aneurysms: Preliminary results from a prospective clinical study. J Neurointerv Surg. 2017;9:772-6. PMID: 28223428 PMCID: PMC5583676 doi: 10.1136/neurintsurg-2016-012896
39. Rice H, Martinez-Galdamez M, Holtmannspötter $M$ et al. Periprocedural to 1-year safety and efficacy outcomes with the Pipeline Embolization Device with Shield technology for intracranial aneurysms: a prospective, postmarket, multicenter study. J Neurointerv Surg. 2020. http://dx.doi.org/10.1136/neurintsurg-2020-015943

40. Atasoy D, Kandasamy N, Hart J et al. Outcome study of the Pipeline Embolization Device with Shield Technology in Unruptured Aneurysms (PEDSU). AJNR Am J Neuroradiol. 2019;40:2094101. PMCID: PMC6911729 EMSID: EMS84586 PMID: 31727754 doi: 10.3174/ajnr.A6314

41. Manning MW, Cheung A, Phillips TJ, Wenderoth JD. Pipeline Shield with single antiplatelet therapy inaneurysmal subarachnoid hemorrhage: multicenter experience. J Neurointerv Surg. 2019;11:694-8. PMCID: PMC6582735 PMID: 30552166 doi: 10.1136/ neurintsurg-2018-014363

42. Lenz-Habijan T, Bhogal P, Peters M et al. Hydrophilic stent coating inhibits platelet adhesion on stent surface: Initial results in vitro. Cardiovasc Intervent Radiol. 2018;41:1779-85. PMCID: PMC6182755 PMID: 30039502 doi: 10.1007/s00270-018-2036-7

43. Aguilar-Perez M, Hellstern V, AlMatter M et al. The p48 flow modulation device with Hydrophilic Polymer Coating (HPC) for the treatment of acutely ruptured aneurysms: early clinical experience using single antiplatelet therapy. Cardiovasc Intervent Radiol. 2020;43:740-7. PMID: 32030488 PMCID: PMC7196938 doi: 10.1007/ s00270-020-02418-4

44. Pierot L, Liebig T, Sychra V et al. Intrasaccular flow-disruption treatment of intracranial aneurysms: preliminary results of a multicenter clinical study. AJNR Am J Neuroradiol. 2012;33:1232-8. PMID: 22678844 doi: 10.3174/ajnr.A3191

45. Pierot L, Klisch J, Cognard C et al. Endovascular WEB flow disruption in middle cerebral artery aneurysms: preliminary feasibility, clinical, and anatomical results in a multicenter study. Neurosurgery. 2013;73:27-35. doi: 10.1227/01.neu.0000429860.04276.c1

46. Lubicz B, Klisch J, Gauvrit JY et al. WEB-DL Endovascular treatment of wide-neck bifurcation aneurysms: short- and midterm results in a European study. AJNR Am J Neuroradiol. 2014;35:432-8. doi: https:// doi.org/10.3174/ajnr.A3869

47. Mine B, Pierot L, Lubicz B. Intrasaccular flow-diversion for treatment of intracranial aneurysms. Expert Rev Med Devices. 2014;11:315-25. PMID: 24694000 doi: 10.1586/17434440.2014.907741

48. Papagiannaki C, Spelle L, Januel AC et al. WEB intrasaccular flow disruptor-prospective, multicenter experience in 83 patients with 85 aneurysms. AJNR Am J Neuroradiol. 2014;35:2106-11. http://dx.doi. org/10.3174/ajnr.A4028

49. Pierot L, Klisch J, Liebig T et al. WEB-DL endovascular treatment of wide-neck bifurcation aneurysms: long-term results in a European series. AJNR Am J Neuroradiol. 2015,36:2314-9. doi: https://doi. org/10.3174/ajnr.A4445

50. Pierot L, Moret J, Turjman F et al. WEB $\AA$ treatment of intracranial aneurysms: Indications, Feasibility, 
Complications, and One-month Safety Results with WEB-DL and WEB-SL/SLS in the French Observatory. AJNR Am J Neuroradiol. 2015;36:922-7. pmid:25655876 doi: 10.3174/ajnr.A4230

51. Pierot L, Costalat V, Moret J, et al. Safety and efficacy of aneurysm treatment with WEB $\AA$ : Results of WEBCAST Study. J Neurosurg. 2016 ;124:1250-6. PMID: 26381253 doi: 10.3171/2015.2.JNS142634

52. Pierot L, Moret J, Turjman F, et al. WEB treatment of intracranial aneurysms: Clinical and anatomical results in the French Observatory. AJNR Am J Neuroradiol. 2016;37:655-9. doi: https://doi.org/10.3174/ajnr. A4578

53. Pierot L, Spelle L, Molyneux A, Byrne J. Clinical and anatomical follow-up in patients with aneurysms treated with WEB device: one-year follow-up report in the cumulated population of 2 prospective, multicenter series (WEBCAST, French Observatory). Neurosurgery. 2016;78:133-41. PMID: 26552042 PMCID: PMC6975162 doi: 10.1227/ NEU.0000000000001106

54. Pierot L, Gubucz I, Buhk JH, et al. Safety and efficacy of aneurysm treatment with WEB $\AA$ : Results of WEBCAST 2 Study. AJNR Am J Neuroradiol. 2017;38:1151-5. doi: 10.3174/ajnr.A5178

55. Pierot L, Moret J, Barreau X, et al. Safety and efficacy of aneurysm treatment with WEB in the cumulative population of three prospective, multi- center series. J NeuroIntervent Surg. 2018;10:5539. PMID: 28965106 PMCID: PMC5969386 doi: 10.1136/neurintsurg-2017-013448

56. Fiorella D, Molyneux A, Coon A, et al. Demographic, procedural, and 30-day safety results from the WEB Intra-saccular Therapy Study (WEB-IT). J NeuroIntervent Surg. 2017;9:1191-6. http://dx.doi.org/10.1136/ neurintsurg-2016-012841

57. Pierot L, Biondi A, Narata AP, et al. Should indications for WEB aneurysm treatment be enlarged? Report of a series of 20 patients with aneurysms in "atypical" locations for WEB treatment. J Neuroradiology. 2017;44:203-9. doi: 10.1016/j.neurad.2016.12.011

58. Van Rooij SB, van Rooij WJ, Peluso JP, Sluzewski M. The Wowen EndoBridge (WEB) as primary treatment for unruptured intracranial aneurysms. Interv Neuroradiol. 2018; 24:475-81. PMID: 29768963 PMCID: PMC6116134 doi: 10.1177/1591019918772174

59. Pierot L, Moret J, Barreau X, et al. Aneurysm treatment with woven endobridge in the cumulative population of 3 prospective, multicenter series: 2-year follow-up. Neurosurgery. 2020 Aug 1;87(2):357-367. doi: 10.1093/neuros/nyz557.

60. Pierot L, Szikora I, Barreau X, et al. Aneurysm treatment with WEB in the cumulative population of 2 prospective, multicenter series: 3-year follow-up. J NeuroIntervent Surg. 2020 doi: 10.1136/neurintsurg-2020-016151

\title{
ОТ РЕДАКЦИИ: КАКОЕ БУДУЩЕЕ У ЭНДОВАСКУЛЯРНОГО ЛЕЧЕНИЯ ВНУ- ТРИЧЕРЕПНЫХ АНЕВРИЗМ?
}

\author{
LAURENT PIEROT \\ Reims University Hospital, France
}

Разрыв внутричерепной аневризмы часто приводит к смерти или инвалидизации пациентов. Поэтому в случае разрыва обязательным и неотложным является раннее лечение аневризмы. Распространенность асимптомных внутричерепных аневризм в популяции продолжает увеличиваться благодаря усовершенствованию инвазивных и неинвазивных технологий нейровизуализации. Учитывая все демографические факторы, сопоставление рисков наличия аневризмы и хирургии, выключение аневризмы является необходимым и положительно влияет на исход лечения у этих пациентов. Эндоваскулярные методы при лечении аневризм головного мозга стали ведущим направлением в течение последних 20 лет и последующие достижения закрепили этот статус еще больше. В настоящее время эндоваскулярный арсенал продолжает стремительно увеличиваться. Нейроинтервенционные операции становятся все более эффективными, повышается их безопасность, совершенствуются методы. Однако использование стандартных эндоваскулярных методов для лечения некоторых типов аневризм может привести к неблагоприятным последствиям. Во-первых, их не всегда можно применить в случае сложных и больших аневризм с большой шейкой. Во-вторых, не во всех случаях можно достичь долговременной радикальности окклюзии аневризм после использования техники ремоделирования и протекционного стентирования. Применение новых устройств расширяет возможности эндоваскулярного лечения. Двумя новыми инновационными методами, которые все чаще используют в эндоваскулярной практике, являются потокоотклонение (Flow Diversion Device) и интрасаккулярные окклюзирующие устройства с потокотклоняющими свойствами (Intrasaccular Flow Distraction Device). Цель этого обзора - всесторонне проанализировать применение этих устройств, выявить ограничения и перспективы. Очевидное 
преимущество новых технологий обосновывает их более частое использование, что в будущем позволит в большинстве случаев заменить стандартную технику койлинга. Усовершенствование инструментов для внутрисосудистого доступа, навигации и доставки различных окклюзионных устройств способствует увеличению количества пациентов, у которых используют интервенционные методы, а не микрохирургическое клипирование.

Ключевые слова: внутричерепные аневризмы; эндоваскулярное лечение; потокоотклонение; интрасаккулярные окклюзирующие устройства с потокотклоняющими свойствами.

\title{
ВІД РЕДАКЦЇ̈: ЯКИМ Є МАЙБУТНЄ ЕНДОВАСКУЛЯРНОГО ЛІКУВАННЯ ВНУ- ТРІШНЬОЧЕРЕПНИХ АНЕВРИЗМ?
}

\author{
LAURENT PIEROT \\ Reims University Hospital, France
}

Розрив внутрішньочерепної аневризми часто призводить до смерті або інвалідизації пацієнтів. Тому в разі розриву обов'язковим і невідкладним є раннє лікування аневризми. Поширеність асимптомних внутрішньочерепних аневризм у популяції продовжує збільшуватися завдяки вдосконаленню інвазивних і неінвазивних технологій нейровізуалізації. 3 огляду на всі демографічні чинники, зіставлення ризиків наявності аневризми i хірургії, виключення аневризми є необхідним і позитивно впливає на наслідок лікування у цих пацієнтів. Ендоваскулярні методи при лікуванні аневризм головного мозку стали провідним напрямом протягом останніх 20 років і наступні досягнення закріпили цей статус ще більше. Нині ендоваскулярний арсенал продовжує стрімко збільшуватися. Нейроінтервенційні операції стають дедалі ефективнішими, підвищується їх безпечність, удосконалюються методи. Однак використання стандартних ендоваскулярних методів для лікування деяких типів аневризм може призвести до несприятливих наслідків. Поперше, їх не завжди можна застосувати в разі складних і великих аневризм з великою шийкою. По-друге, не в усіх випадках можна досягти тривалої радикальності оклюзії аневризм після використання техніки ремоделювання і протекційного стентування. Застосування нових пристроїв розширює можливості ендоваскулярного лікування. Двома новими інноваційними методами, які дедалі частіше використовують в ендоваскулярній практиці, є потікскерування (Flow Diversion Device) та інтрасакулярні оклюзійні пристрої з потікскерувальними властивостями (Intrasaccular Flow Distraction Device). Мета цього огляду - всебічно проаналізувати застосування цих пристроїв, виявити обмеження і перспективи. Очевидна перевага нових технологій обгрунтовує їх частіше використання, що в майбутньому дасть змогу в більшості випадків замінити стандартну техніку коілінга. Вдосконалення інструментів для внутрішньосудинного доступу, навігації та доставки різних оклюзійних пристроїв сприяє збільшенню кількості пацієнтів, у яких використовують інтервенційні методи, а не мікрохірургічне кліпування.

Ключові слова: внутрішньочерепні аневризми; ендоваскулярне лікування; потікскерування; інтрасакулярні оклюзійні пристрої з потікскерувальними властивостями. 